$674 \quad$ NATURE April 30, 1949 Vol. 163

Virus Diseases of Lettuce

DANDELION yellew mosaic virus was first reported by B. Kassanisin 1944. He then showed that the diseast could so affect lettuce. More recently ( $A n n$. A2p. Bjol. 44, No. 3, 412-421; Sept. 1947) the same ate haf described the symptoms and transmission of d ndell $n$ yellow mosaic and of lettuce mosaic. Fe 1 so reports the isolation of cucumber mosaic f. $\mathrm{m}$ naturally infected lettuce. Lettuce is more susceptible to dandelion yellow mosaic than is its name host. The aphid Myzus persicae transmits lettuce mosaic, but not dandelion yellow mosaic, which is, however, spread by Myzus ornatus, $M$. ascalonicus and Aulacorthum solani. The common lettuce aphid, Nasonovia ribicola, rather perversely transmitted neither virus. Lettuce mosaic is found in most samples of commercial seed; but dandelion yellow mosaic is not seed-borne.

\section{Frank B. Jewett Fellowships: New Awards}

THE American Telephone and Telegraph Co. has awarded the Frghk B. Jewett Fellowships for 1949-50 to the following: Dr. Harish-Chandra, a graduate in mathematics and theoretical physics of the University ff Allahabad, the Indian Institute of Science in Bangolore and the University of Cambridge, who has gone considerable research on the theory of elenentary particles and is at present working on the theory of Lie algebras at the Institute for Advanced Study, Princeton; Dr. James A. Jenkins, a graduate in mathematics and physics of the University of Toronto and Harvard University, who is engaged in research relating to topological mapping problems at Harvard University ; Dr. Robert Karplus, a graduate in chemical physics of Harvard University, who is engaged in nuclear research at the Institute for Advanced Study, Princeton; Dr. Joaquin Mazdak Luttinger, a graduate in physics of Brown University and the Massachusetts Institute of Technology, who has been studying at the Physikalisches Institut, Zurich, and will continue his research there on the theory of the supercon. ductive state; Dr. David Emerson Mann, a graduate in physics and chemistry of the City College of New York and of the University of Chicago, who is engaged in research in quantum mechanics at the University of Minnesota; Dr. Harvey Winston, a graduate in chemistry of Columbia College, who will undertake research in crystallography. These fellowships are designed to stimulate and assist post. doctorate research in the fundamental physical sciences and are awarded on the recommendation of a committee of seven from the Bell Telephone Laboratories. The awards carry a grant of 3,000 dollars to the recipient and 1,500 dollars to the institution at which the research is done.

\section{Textile Institute: Awards}

Dr. D. A. Curbeens, of the British Cotton Industry Research Association, has been made an honorary fellow of the Textile Institute, in recognition of his work on the chemistry of cellulose and the development of malytical and testing methods for the control of bleaching, mercerizing and dyeing. This distiyction has only been conferred on eight previous ocgusions. Dr. S. A. Shorter, formerly of the British Cotton Industry Research Association, has been awarded the Warner Memorial Medal, in recognition of original investigation, the results of which have been published in the Journal of the Institute.
The Institute Medal, for distinguished services to the textile industry in general and to the Institute in particular, has been awarded to Messrs. A. W. Bayes and Harold Ashton, and the Service Medal, for valu able services rendered to the Institute, to Messrs. H. C. Barnes and S. Kershaw.

\section{Symposium on Engineering Structures at Bristol}

THE Colston Research Society has arranged with the Univer ty of Bristol a series of symposia, to be held annually, on selected research topics of current importance. The first of these, on cosmic rays, took plage last September, and the second, on engineering structures, will be held during September 19-23. At this symposium the papers read will deal mainly with non-linear aspects of the behaviour of engineering structures ; but some more general papers reviewing research work on various kinds of engineering structures will be included. A number of men of science, well known in this field, have been invited, and the symposium will be open to all research workers and students connected with this subject. However, the numbers will be limited to eighty, and requests for admission should be sent, before July 1, to Prof. A. G. Pugsley, Merchant Venturers' Technical College, Bristol 1.

\section{The Night Sky in May}

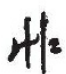

Furs moon occurs May 12d. 12h. 51m., U.T., and new mogr o valy 27 d. $22 \mathrm{~h}$. $24 \mathrm{~m}$. The following conjunctions the moon take place: May 6d. 20 h., Salat $3^{\circ}$ S. ; May 17d. 14h., Jupiter $5^{\circ}$ N.; May 26d 16h., Mars $2^{\circ}$ S.; May 27d. 12h., Mercury 0. $2^{\circ}$ Mercury is an evening star, setting at $21 \mathrm{~h}$. 16.m., 21h. $43 \mathrm{~m}$. and $20 \mathrm{~h} .16 \mathrm{~m}$., at the beginning, ndddle and end of the month, respectively; but in the latter case it is too close to the sun to be observed. The planet attains its greatest eastern elongation on May 10. Venus is an evening star and can be seen for a short time in the western sky after the middle of the month, setting $35 \mathrm{~min}$. and nearly an hour after the sun on May 15 and 31, respectively. Mars is a morning star but rises too soon before the sun for favourable observation. Jupiter rises at $1 \mathrm{~h} .30 \mathrm{~m}$., $0 \mathrm{~h} .35 \mathrm{~m}$. and $23 \mathrm{~h}$. $33 \mathrm{~m}$., on May 1,15 and $3 \mathrm{I}$, respectively, and is visible for a few hours before sunrise. The planet is stationary on May 20. Saturn is visible until after midnight, setting at $2 \mathrm{~h} .40 \mathrm{~m}$., $\mathrm{lh}$. $45 \mathrm{~m}$. and $0 \mathrm{~h} .45 \mathrm{~m}$., at the beginning, middle and end of the month, respectively, and is stationary on May 1. Only one occultation of stars brighter than magnitude 6 occurs, $\lambda$ Canc. disappearing at $2 \mathrm{lh}$. $30 \cdot 6 \mathrm{~m}$. on May 4 .

\section{Announcements}

THE L. T. Hobhouse Memorial Trust Lecture will be delivered at King's College, University of London, on May 12, at 5.30 p.m., by Prof. V. Gordon Childe, professg $/$ of prehistoric European archæology in the Univgrsity of London, who will speak on "Social Wolds of Knowledge". Admission will be free, without ticke.

A RESEARCH scholarship of the value of $£ 400$ per annum ghd tenable for two years has been offered by the Aluminium Development Association to en. courage and facilitate research in the application of light alloys to ship construction. Full particulars of entry, which closes on July 31, can be obtained from the Secretary, Institution of Naval Architects, 10 Upper Belgrave Street, London, S.W.1. 